\title{
Political Economy and Regional Policy: The Impact of US-China Trade Tension on the Global Economic Growth
}

\author{
Sunkung Danso \\ Master of Science in Sectoral Analysis and Management of the Education System, Graduate School, University \\ of the Gambia, MDI Road, Kanifing, The Gambia, West Africa \\ sunkung.danso@gmail.com
}

\section{Abstract}

This paper uses a systematic literature review to discuss US-China trade tension. The study discusses the US-China trade tension and its impact on the global economy because the US-China trade war is imminent at the point in time since President Trump came to power in 2016. This research aims to examine how US-China trade tension is unfolding and the significant change of this trade tension on the world economy. The systematic literature review was engaged to capture the sequence of the event as they are happening between the US and China with regards to trade barriers. This research reviewed 19 peer-review journals and some news items and WTO resources relevant to this study. This study revealed that the US-China trade tension has affected consumer goods to some extent but it may not affect the global economy currently. However, it is evident that in the long-run; the US-China trade war will have an impact on the lives of people and the global economy if the issue continues to intensify. In conclusion, the economy of the US has declined drastically by $0.8 \%$ while China also experience $0.4 \%$ fall in the economy in 2019. The impact is currently not severe on the global economy but if the tension continues it might have a negative impact on the global economy. The trade deficit is getting wider between China and the US.
Keywords

US-China trade tension; deficit; impact; economy, war

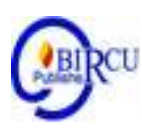

\section{Introduction}

Political economy could be defined as an interaction between politics and economics. The word economy derived from two Greek words such as "Oikos" and "nomos" which means house and order. Moreover, political refers to factors of production and distribution which has gone beyond the level of household production of wealth and its distribution at both state or international level as well as involvement of state actor and non-state actors. The economic theory was impacted by an idea which says market strengths play a major part in stabilizing the cost of merchandise and administrations (Wollie, 2018, p. 1). Political economy deals with the study of factors of production and trade in relations to law, custom and government as well as distribution of national resources or resources in general. It is an interdisciplinary field of study in social sciences that focuses on the interrelationship between individuals, governments and public policy. It also studies economic theories like capitalism, socialism, and communism and how they work in real world. It is important to note that political economy looks into methods of directing the distribution of resources for the benefit of all and sundry. It is evident that the resources are said to be limited while the desires are unlimited. Therefore, political economists advocate for equitable distribution of resources and 
factors of production most be planned, directed, organised, and monitored. In essence, political economy could refer to the advice given by economists to the government on either general economic policies or certain proposals by politicians. According to Lionel Robins (1932) 'economics is the science which study human behaviour in relation to ends and scarce means that have an alternative use'. Political economy in its broader sense study the political nature of decision-making process and how politics shape or affect the economic choice of the society and the globe. In addition, international Political Economy is based on the idea that in spite of the fact that the think about of legislative issues and financial matters, states and markets, is so personally entwined, their relationship merits thought in it possess rights (Söderbaum, 2004, p. 4). Further, Game theory is most appropriate to issues including contracts, participation, conspiracy, political economy and rent-seeking, and bilateral or multilateral showcase control - issues that inalienably bargain with little numbers of players or collective activity (Richard E. Just, Darrell L. Hueth, 2004, p. 405). Essentially, political economy is also interested in settling trade dispute and it deals with trade imbalance. Scholars are actually concern with GATT/WTO dispute settlement and "concerns the law's actual effects on either domestic or international political behaviour and only a handful of studies have ever compared large number of cases in any systematic fashion" (Kennedy \& Southwick, 2002, p. 458). Hudec (1993) is one of the scholars who contribute on the discourse of political economy of dispute settlement and he made a distinction between panel ruling and dispute outcome. Hudec further reiterate that in making this distinction, he energizes researchers to think around dispute settlement in an unmistakably political way, inquiring approximately the components that lead governments to create concessions within the wake of a panel ruling (Kennedy \& Southwick, 2002, p. 458).

Moreover, it is argued that regional policy is the governments' policy to help improve the economic conditions of the member countries particularly trade and other patent issues. It might also include political and cultural policies which is gear toward promoting democratic cultures in that region and building social cohesion among member states. However, it important to note that its main aim is to improve economic activities in the region to help the disadvantage countries to trade with advantage countries on fair custom tariff. For instance, the OECD Southeast Asia programme is geared towards encouraging the systematic exchange of experience to develop common solutions to regional and global challenges. Regional Policy Networks (RPNs) and Initiatives focuses on issue of tax, good regulatory practices, investment policy and promotion, education and skills development, Small and Medium-sized Enterprises (SMEs) and Public - Private Partnership to support infrastructural development in Southeast Asia. The Economic Outlook for Southeast Asia, China, and India serves as a monitoring tool for medium-term macroeconomic trends and regional integration to identify the emerging trends in the region in order to offer advices or recommendations accordingly. Essential features of regional policy are to deal with economic imbalances among the member states and encourage trade liberalization. It is argued that "political scientists are first and foremost concerned with power politics and inter-state regional frameworks; economists with regional economic flows and the economic consequences of policy shifts while sociologists and social anthropologists with regional sociocultural relations" (Söderbaum, 2004, p. 5). Comprehensive analysis of regional policy involves multi-disciplinary approach to decision making process to deal with diversity and geographical difference.

Historically, it was after the World War II that nations which share similar cultural and geographic or geopolitical history came together to form regional bloc to help improve the economy of the member states. The political economy of regional policy is to connect the 
nations and promote economic activities among the nations. Historically, in July 1944 immediately after World War II 44 countries converged to discuss a way forward and to control their economic relations and the conference is called Bretton Woods Conference. Consequently, "two international economic organisations resulted from the conference such as the International Monetary Fund (IMF) and International Bank for Reconstruction and Development (IBRD) which was later changed to World Bank in 1948, the General Agreement on Tariffs and Trade (GATT) became the main global trade organisation"(Cohn, 2016). These institutions were tasked to shape and manage the post-war global economy which resulted to the formation and implementation of Marshall plan in Western Europe in 1948 to revive those nations that were seriously affected by the war.

China and US are very important players in the world economy and they are among the biggest economies in the world which are very key actors in international trade. US-China trade tension has a long-standing background but it became eminent during the Donald Trump's administration. In 1930, within the middle of the Great Depression, the US raised tariff s on imported merchandise as a result of the execution of the Smoot-Hawley Act. That activity activated a tit- for- tat response from other nations, coming about within the annihilation of worldwide trade and making the Great Depression indeed more prominent. Since almost 2005 the risk of a trade war has gotten to be genuine, symbolized by calls for the burden of tariffs on US imports from China (Moosa, 2012, p. 1). US-China trade war commenced shortly when Trump took office in 2016. Some trade barriers were introduced between US and China in which Trump said that the trade between China and US is not at the advantage of the US and in 2017, an additional tariff was levied on Chinese products to US Market. It is argued that "in the process of globalization, China and the U.S. are partners and competitors. Given their economic size, a stable China-U.S. economic relationship is the foundation of a healthy global economic order. In recent years, especially since President Trump took office in the U.S., tensions between these two countries have been on the rise. According to World Trade Organization (WTO) statistics, the United States has initiated trade dispute lawsuits against other countries in the world 131 times, including 23 times against China, which is the country with the largest number of legal actions in the United States"(Xia, Kong, Ji, \& Zhang, 2019). China is biggest producer of energy in the world while US is the second largest producer of energy. In the same vein, China is largest producer of food in the world while US is the third world producer of food and India is the second largest producer of food.

Moreover, "the US tariffs increment to 25 percent on \$200 billion of annual Chinese imports on May 10th, 2019 together with the announced Chinese retaliation marks the latest escalation in the US-China trade tensions. The impact of previously imposed tariffs by the US and subsequent retaliation by China is already evident in trade data since both the countries are directly involved and their trading partners have been affected by increasing tariffs" (Hassan Hakimian, 2014; Sondang Ni Bulan Marbun \& Donna Maryati Panggabean, 2020). In 2018, the US imposed tariffs sequentially on three "lists" of goods from China, targeting first $\$ 34$ billion of annual imports followed by $\$ 16$ billion more as well as an additional $\$ 200$ billion which make it $\$ 250$ billion in total. Concomitantly, "the records issued by the US and China comprise of two sets of items, which are esteemed at 34 billion and 16 billion US dollars, individually. The US re-examined its duty list on June 15, and the extra taxes of 25 per cent forced on the primary set of items went into effect on July 6, 2018. The second set of items issued by the US experienced encourage audit in a public notice and comment handle some time recently the US Trade Representative (USTR) issued the last assurance with respect to the items on this list that are subject to extra obligations of 25 per cent in August 2018" (Tu, Du, Lu, \& Lou, 2020, p. 3). As a result, US imports from China 
have declined very strongly in all three bunches of the products on which taxes were forced. In these cases, where there was a delay between declaration and usage of taxes within the case of the $\$ 16$ billion and $\$ 200$ billion records or plans to stage within the duty increment as within the case of the $\$ 200$ billion records. This recommends that merchants supplied up ahead of the duties and it is an account for the more honed decay in imports from there on. Consequently, "the tariffs went into effect on September 24, 2018, at an introductory rate of of10 per cent and were reported to be expanded to 25 per cent by January 1, 2019" (Tu et al., 2020, p. 3). It is stressed that "President Trump's Twitter diplomacy, recently outlined by the declaration of extra duties of 10 per cent on the US $\$ 300$ billion worth of Chinese imports not however burdened from September 2019, does not energize a fast resolution of trade negotiations between China and the USA" (Goulard, 2020, p. 56).

In addition, China imposed retaliatory tariffs on US exports to China has declined. "In reaction, China actualized extra taxes of 5 or 10 per cent on a list of items worth 60 billion US dollars on September 24, 2018"'(Tu et al., 2020, p. 3). The front-loading dynamic is not evident in this case and US export growth to China has been generally weaker since the trade tensions began. Further, the share of emerging economies in global trade has also grown from 28.2 percent to 43.4 percent of total global trade in the past two decades. Even when extractive commodity trade is excluded, the share of emerging economies in global trade has grown from 27.1 percent to 41.4 percent over the period. Emerging economies increasingly participated in global trade through contributions to regional segments of GVCs; while systematic regional data are uneven. It is clear that most Eastern European countries and newly industrializing nations of Asia as well as some Latin American countries such as Mexico have deepened their participation by increasing their production into segments of larger value chains and trade diversion which comes with some cost.

\section{Review of Literatures}

Within the pattern of trade relations, there's a term called the upstream and downstream trade relations. The relationship of upstream and downstream trade is exchanging between inland regions with coastal ranges or upland and marsh zones (Suprayitno, Ratna, \& Handoko, 2019, p. 298). Therefore, China and US are among the world's biggest economy and they are key plays in the global economy. Recently, China has become more developed and its role in the international economic system has been widely discussed. Some economists tend to view these developments as more positively. For example, Taylor (2016) ) 'proposed that an improvement in China, particularly showcase advancement and financial development can be of advantage to US and hence ought to be empowered by the US and other nations' (Zhang, Lei, Ji, \& Kutan, 2019). It was predicted that China's economic growth will be persistent and will affect the world economy through trade and investment. They suggested that both less-developed and developed economies such as the US and Germany can benefit from China's continued growth. China's outward foreign direct investment (FDI) has increased significantly since the 2008 global financial crisis, not only in less-developed countries of Africa but also in middle income counties in Asia. Despite China's open-door policy and her economic expansion, their trade policy does not go down well with the Western world particularly the US under Trump's Administration. Arguably, the Chinese policies that are being assaulted by the US are similarly disliked in Europe. Reactions with respect to the burglary of intellectual property in common and trade secrets, to be specific, are frequently disclosed within the European press and in regrets of governments and the private sector, as are complaints with respect to the treatment of the foreign partners of its multinationals (Plummer, 2019, p. 195). 
Certainly, the US-China trade strife has influenced markets well past trade; strife makes instability, which weighs on certainty within the future and, subsequently, speculation. But the greater longer-term issue relates to the wellbeing and judgment of the worldwide framework (Plummer, 2019, p. 196). Further, there's an agreement among world leaders and banks almost the threats of the current US-China trade war on the world economy. For former US Treasury Secretary Lawrence Summers, the world is at the foremost unsafe budgetary minute since 2009 (Yeung, 2019 in (Goulard, 2020, p. 57). The history also taught us that trade war affect both sides and, in this case, it has contributed to global economic slowdown which makes many scholars and professional to be worry some since the consequence could not be estimated. Bothe countries continue to make strife tariffs. For Jean-Claude Juncker, the European Commission President, "the trade relations between China and the United States are troublesome, they are contributing to the lull of the worldwide economy" (Rampton, 2019 in (Goulard, 2020)). For the French bank "Société Générale" (Xu, 2018 in (Goulard, 2020)), the trade war between the USA and China might not lead to a worldwide monetary emergency but might affect the development of Asian economies. This finding is shared by the IMF (2019 in ibid); agreeing to Ms Christine Lagarde, the US-China trade war may diminish the level of worldwide GDP by US $\$ 455$ billion in 2020 (Goulard, 2020, p. 57). In addition, many economists also warn that China's economic growth could slow further if the United States and China continue to impose punitive economic measures against each other, such the tariff hikes that have resulted from U.S. action under Section 301 and Chinese retaliation. The Organization for Economic and Cooperation and Development (OECD) projected an increase in tariffs on all trade between the United States and China could reduce China's real GDP in 2021-2022 by $1.1 \%$ relative to the OECD's baseline economic projections (CRS, 2019, p. 23).

\section{Research Methods}

This research employs a systematic literature review in this study. The systematic literature review examines peer-reviewed journal, books, news items and google search engine to collect information from different sources that are relevant to this study. Search was carryout in online databases such as Scopus journal, google scholar, WTO resources, and New items. This help to gather the relevant information to analysis the trade tension between China and US. The key words search to collect the relevant journal articles and other information to this research are US-China Trade War, impact, global economy. A literature review may be a central device for the dispersal of information for both investigate and hone. A carefully conducted, thorough, and a keen blend of the writing on the issue at hand is a basic beginning point for all scholastic voyages of discovery (Watson, 2015, p. 185). Further, in spite of the fact that Google Scholar has ended up a valuable apparatus for researchers, it could be a crude way of looking for journal content. An article is basically an enormous sack of words destitute of semantics (Watson, 2015, p. 187).

This is explicitly descriptive and most importantly it begins with planning and definition of concepts. "The literature review started with planning phase and definition of the review protocol" (Sarmento \& Simões, 2018, p. 155). Therefore, this research uses simple systematic literature review to gear the impact of UN-China Trade tension. On that note, this research is purely desk review. The research has systematically review 19 peer-reviewed journal articles and some websites relevant to this study. 


\section{Discussion}

\subsection{Trade Liberalization Theories.}

The theoretical framework used in this discourse is trade liberalization and liberal perspectives will help explain free market concepts in the political economy. In addition, liberal addresses various actors in international trade and employ different levels of analysis. There are three distinct liberal theories such as orthodox liberal, interventionist liberal, and institutional liberal. These liberal theories will be explained in turn as follows. Arguably, "orthodox liberals promote "negative freedom" or freedom of the market to function with minimal interference from the state. Interventionist liberals believe that negative freedom is not sufficient, and they support some government involvement to promote more equality and justice in a free market economy (an economy in which the market coordinates individual choices to determine the types of goods and services produced). Institutional liberals also view some outside involvement as necessary to supplement the market, and they favour strong international institutions such as the WTO, IMF, and World Bank" (Cohn, 2016). Therefore, such institutions should intervene between US and China to put an end to this trade conflict because its consequences are not limited to them only. It is vital to acknowledge that liberals' theories engaged different methods in studying international political economy. Perhaps, rationalism and constructivism will give a concrete understanding about international trade and international political economy. The orthodox liberals alluded that the invisible hands in the market enables the market to preform efficiently while the society regulate herself with little or no interference from the government. However, Adam Smith was with conviction that the state has some role to play. Furthermore, "liberal principles are politically neutral and that states benefit from economic growth and efficiency when their policies conform to those principles" (Cohn, 2016). It is evident that states policies must be in conformity with liberal economic principles when the state acted neutral in the market, otherwise resource allocation will be inefficient and economic growth will be negative or weak. On that note, China and US should be adhere to rule and regulation laid down by GATT/WTO with regards to non-tariff barriers to trade.

\subsection{US-China Trade Tension and its Impact of Global Economy}

The US-China trade tension is a concern for all nations in the world as they are two biggest economies of the world. The fact that trade liberalisation has been growing steadily in the world with expansion rate of $4.2 \%$ annually and $6.3 \%$ respectively for developing countries by 2018 . According to WTO statistics (2018), "world trade volume today are roughly 40 times the level recorded in the earlier days of the GATT (4136\% growth from $1950-2018$ )'. The trend seems to have change if this trade conflict continues between the world biggest economies. The US-China trade war has a long history since 1930 and high rate of Chinese economic advancement is also threat to the US economic status in the globe. However, US-China trade war began when President Donald Trump came to power in 2017 which gets worsen in 2018. Later that year, the two economic super powers are engaged into negotiations upon negotiation which is refer to as 'tit-for-tat tariff war'. The US imposed tariff on import from China was in three phases such as first was in summer 2018 US imposed $\$ 50$ billion dollars, second was $\$ 200$ billion US dollars in September, 2018 and third was in September, 2019 in the sum of $\$ 300$ billion US dollars respectively (Nicita, 2019, p. $3)$. The total US imposed tariff is $\$ 550$ billion US dollars' worth of Chinese products exported to US market as of September, 2019. In response, the China also levied tariff of $\$ 185$ billion US dollars' worth of US goods exported to China. These action of US left China 
with no choice but to look for options or alternatives rather than tariff tit-for-tat tariff war. China did what is called trade diversion. However, trade diversion is costly but necessary for at this point in time for China because US is not compromising with China. Besides, within the case of tariffs applied as it were to specific countries, as within the United States-China trade war, duties can lead to trade preoccupation impacts as importers can maintain a strategic distance from the tariffs by sourcing the products from somewhere else. Trade diversion impacts don't essentially happen, and for the most part are not total, meaning that third nations are by and large able to capture as it were a portion of the trade, with the rest being misplaced or internalized by the nation imposing the tariff (Nicita, 2019, p. 4). For example, China is now importing Soybeans from Brazil which they used to import from US. Based on the three retaliation records issued by China, add up to $\$ 17,207$ million of Chinese imports might be diverted from the US to other sources including Brazil, Germany, Japan, South Korea and the United Kingdom (Tu et al., 2020, p. 4).

Moreover, in the same year, 2018, President Trump threatened to impose an additional tariff of $\$ 200$ billion which was regard by China as a blackmail from President Trump and Beijing report that they will take both quantitative and qualitative measures to retaliate to the threats made by US. Trump's decision has badly hit the Shanghai's stocks market which resulted to a decline of $4 \%$ percent and governor of Central Bank of China urge investors to 'stay calm' in which the Central Bank will endeavour to keep the systemic risk at bay, he asserted. In sperate engagement, the Ministry of Commerce of Chinese government was quoted of stating that Chinese government is considering option than tariffs as tit-for-tat trade war . Apparently, TAD estimates that EU exports would be the chief recipient of a raised USChina trade war, with the EU capturing $\$ 70$ billion ( $\$ 50$ billion of Chinese trades to the United States and \$20 billion of US sends out to China),(Plummer, 2019, p. 196). This is evident that the EU could benefit a lot with this trade conflict between US and China. The US denied the Chinese Tech giant from accessing the US domestic market and Beijing reported in May, 2019 that 'it will create a blacklist of unreliable foreign firms and individuals which marks a new escalation from the side of China .

Furthermore, the impact of US-China trade war on the global economy could not be very significant as of now but it could be huge in the long-run and third-party countries could suffer from the consequences of the trade war. It is argued that in a trade war, the two belligerents are economically impacted, as Chinese President Xi Jimping said in his speech at the 2017 Davos Forum: "No one can win a trade war", but the effects of a trade war on third parties are relatively difficult to measure'(Goulard, 2020, p. 57). However, this ongoing trade war between US-China can be beneficial to third-party countries. For example, it is projected that the EU could benefit about $\$ 70$ billion US Dollars from the trade tension between US and China. According to a study conducted by the Japanese bank Nomura (Subbaraman, Varma, \& Loo, 2019 in (Goulard, 2020)), Vietnam was the first nation to benefit from the trade war between the USA and China picking up nearly 9 per cent of GDP from trade diversion (Goulard, 2020, p. 57). Further, It is alluded that 'from the point of view of implications of the Sino-US trade war on the worldwide trade, maybe a scale-up in costs of foreign products within the home nation, trade diversion, and mutilations in worldwide esteem chains appear inescapable' (Vlados, 2020, p. 7). Vlados (2020) stressed that;

"This trade war has moreover demonstrated that the instrument of the WTO to settle trade disputes is likely dysfunctional. The need for certainty in WTO to change members' retroactive financial misfortunes appears self-evident. According to Adekola (2019), the WTO is on the skirt of getting to be dysfunctional, with individuals turning to "self-help" without response to the rules and strategies of the organization for dispute settlement. He 
emphasizes that presently is the time for changes to fortify the multilateral trading framework" (Vlados, 2020, p. 8).

US-China trade tension should be handled by WTO's dispute settlement mechanisms like GATT but it is like these mechanisms are dysfunctional or neglected by US and China.

\section{Conclusion}

In conclusion, I will reiterate the say 'no one can win the trade war'. Both US and China are affected in terms of their decline in trade figures for imports and exports. The ratcheting up of bilateral tariffs between the US and China has had a limited effect on their bilateral trade balance. It is observed that in 2018, the US trade deficit increased while imports from China went up which partly reflected the trade numbers. Evidently, the tariff war will have spill over impacts to other ranges past trade on both nations and also the globe, including declining domestic and foreign investment, collateral harm along the worldwide value chain and turbulence within the world trading framework (Tu et al., 2020, p. 20). This means that no nation is immune to the trade dispute between the two economic super powers.

Bilaterally, macroeconomic components including relative aggregate demand and supply in partner nations and their fundamental drivers play a much greater part than tariffs in deciding bilateral trade balances. At the global stage, the additional impact of the recently declared tariffs and imagined new US-China tariffs, anticipated to amplify all trade between those nations which will subtract approximately 0.3 per cent of worldwide GDP within the brief period possible. Besides, a failure to resolve trade differences and assist acceleration in other zones such as the auto industry which would cover several nations. This will slow down many economic activities globally as well as slow investment and trade.

In addition, the higher trade barriers would disrupt worldwide supply chains and moderate the spread of modern innovations which will eventually bring down worldwide efficiency and welfare. Further import restrictions would overover make tradable customer goods less reasonable in price and harmoniously low-income families excessively. Basically, this trade war between the US and China is unfolding and neither US nor China could be declared the winner of this trade war. Finally, the impact of the US-China trade war has little or no effect on the global economy but in the long run, its impact will be noticed and developing countries will suffer the consequences. In conclusion, the economy of US has declined drastically by $0.8 \%$ while China also experiences $0.4 \%$ fall in economy in 2019 . The impact is currently not severe on the global economy but if the tension continues it might have a negative impact on the global economy. The trade deficit is getting wider between China and the US.

\section{References}

Cohn, T. H. (2016). Global Political Economy (17th Editi). Retrieved from www.routledge.com/9781138958746

CRS. (2019). China' s Economic Rise : History, Trends, Challenges, and Implications for the United States.

Goulard, S. (2020). The Impact of the US-China Trade War on the European Union. Global Journal of Emerging Market Economies, 12(1), 56-68. https://doi.org/10.1177/0974910119896642

Hassan Hakimian, J. B. N. (2014). Trade Policy and Economic Integration in the Middle East and North Africa. In Trade Policy and Economic Integration in the Middle East and North Africa. https://doi.org/10.4324/9780203633908 
Kennedy, D. L. M., \& Southwick, J. D. (2002). The Political Economy of International Trade Law. In Cambridge University Press. Cambridge University Press.

Moosa, I. (2012). The US-China Trade Dispute. In The US-China Trade Dispute. https://doi.org/10.4337/9781781001554

Nicita, A. (2019). Trade and trade diversion effects of United States tariffs on China. UNCTAD Research Paper, (37), 1-17. Retrieved from https://unctad.org/en/PublicationsLibrary/ser-rp-2019d9_en.pdf

Plummer, M. G. (2019). The US-China Trade War and Its Implications for Europe. Intereconomics, 54(3), 195-196. https://doi.org/10.1007/s10272-019-0822-3

Richard E. Just, Darrell L. Hueth, A. S. (2004). The Welfare Economics of Public Policy: A Practical Approach to Project and Policy Evaluation. Edward Elgar Publishing Limited.

Sarmento, M., \& Simões, C. (2018). The evolving role of trade fairs in business: A systematic literature review and a research agenda. Industrial Marketing Management, 73(June 2015), 154-170. https://doi.org/10.1016/j.indmarman.2018.02.006

Söderbaum, F. (2004). The political economy of regionalism. In European Economic Review (Vol. 48). https://doi.org/10.1016/S0014-2921(02)00329-X

Sondang Ni Bulan Marbun, \& Donna Maryati Panggabean. (2020). Effect of Work Compensation and Discipline on Employee Performance in PT. Berjaya Group Medan. Britain International of Humanities and Social Sciences (BIoHS) Journal, 2(2), 470-479. https://doi.org/10.33258/biohs.v2i2.245

Suprayitno, S., Ratna, R., \& Handoko, H. (2019). Salt Trading in Deli: Relationship between Karo and Coastal Area in 19th Century. Budapest International Research and Critics Institute (BIRCI-Journal): Humanities and Social Sciences, 2(4), 298-305. https://doi.org/10.33258/birci.v2i4.618

Tu, X., Du, Y., Lu, Y., \& Lou, C. (2020). US-China Trade War: Is Winter Coming for Global Trade? In Journal of Chinese Political Science. https://doi.org/10.1007/s11366-02009659-7

Vlados, C. (2020). The Dynamics of the Current Global Restructuring and Contemporary Framework of the US-China Trade War. Global Journal of Emerging Market Economies, 12(1), 4-23. https://doi.org/10.1177/0974910119896636

Watson, R. T. (2015). Beyond being systematic in literature reviews in IS. Journal of Information Technology, 30(2), 185-187. https://doi.org/10.1057/jit.2015.12

Wollie, G. (2018). The Relationship between Inflation and Economic Growth in Ethiopia. Budapest International Research and Critics Institute (BIRCI-Journal) : Humanities and Social Sciences, 1(3), 264-271. https://doi.org/10.33258/birci.v1i3.73

Xia, Y., Kong, Y., Ji, Q., \& Zhang, D. (2019). China Economic Review Impacts of China-US trade conflicts on the energy sector. China Economic Review, 58(October), 101360. https://doi.org/10.1016/j.chieco.2019.101360

Zhang, D., Lei, L., Ji, Q., \& Kutan, A. M. (2019). Economic policy uncertainty in the US and China and their impact on the global markets. Economic Modelling, 79(October 2018), 47-56. https://doi.org/10.1016/j.econmod.2018.09.028. 